\title{
Master Recession Curve (MRC) analysis to characterize karst aquifers of several springs in the north side of the Karangbolong (Gombong) karst area
}

\author{
Aulia Ika Rahmawati, Alpine Prima Priambada, Muhammad Qodri Al-Ghozali, Danang \\ Riza Fauzi*, Tjahyo Nugroho Adji, Andy Setyawan, Danung Shodikh Mahrizkhal, Romza \\ Fauzan Agniy, Afid Nurkholis, Ahmad Cahyadi, Elisabeth Supi Astuti, Eko Haryono
}

Karst Research Group, Faculty of Geography, Universitas Gadjah Mada, Indonesia

\begin{abstract}
Karst aquifers have triple porosity (diffuse, fissure, and conduit) which makes their characterization difficult, and often requires a combination of particular methods and investigation over a long period. The purpose of this study is to analyse the components of the flood hydrograph and create a master recession curve (MRC) in karst aquifers that recharge several springs on the north side of the Karangbolong Karst Area (Gombong). The springs studied include Kalisirah, Jumbleng, and Kalikarak springs. The data used are time-series discharges recorded every 15 minutes from November 2018 to March 2020. Furthermore, the reconstruction of the flow regime for MRC is carried out with the help of RC 4.0 software, which is at the same time able to define the level of karst aquifer development. The results showed that Kalisirah and Kalikarak Springs have a complex discharge regime with a degree of karstification in class 8, while Jumbleng Springs in class 5. Analysis of the components of the flood hydrograph reinforces the results of the calculation of the karstification degree. The time to the peak $\left(\mathrm{T}_{\mathrm{lag}}\right)$ of the Kalisirah and Kalikarak Springs is relatively fast (1.94 and 1.44 hours), which indicates that conduit flow has developed, while Jumbleng spring has a longer $\mathrm{T}_{\text {lag }}$ of 2.69 hours. Calculation of time to base flow $\left(\mathrm{T}_{\mathrm{b}}\right)$ both manually (by flood events analysis) and automatically (by MRC) shows that Kalikarak Springs has the longest time with an average of about 31 hours which reflects that karst aquifers which contribute to it are still quite good in storing groundwater, while Jumbleng spring has the fastest $T_{b}$ value with an average of 17.25 hours which reflects the shortest release of water storage compared to the other two springs.
\end{abstract}

\section{Introduction}

Characterization of karst aquifers is known to be difficult because of the nature of tripleporosity (diffuse-fissure-conduit). Flow hydrograph analysis at karst system outlets or springs is a common method used to characterize karst aquifers [1]. A review of several

*Corresponding author : danangrizafauzi07@gmail.com 
methods for the analysis of flow hydrographs at karst system outlets or springs has been carried out by [2], which includes analysis of recession curves, time series, and calculation of flow duration. One of them is constant recession calculation which is a simple method, but it can reflect the characteristics of a karst aquifer in releasing its storage and can indirectly know the level of void development in its aquifer [3].

The application of recession constants in the field of hydrology has experienced many developments. Calculation of recession constants manually, i.e. using graphical methods, was first carried out by [4]. The study separates the recession curve into three flow components, namely overland flow, interflow, and baseflow. The concept is then used by $[5,6,7,8]$ and [9] to calculate the recession constants of conduit flow, fissure, and diffuse in karstic aquifers. These studies use the concept of a single recession curve with the simple exponential form (1) equation, as explained by [10]. In addition, [11] also has some equations for calculating recession curves in a discharge hydrograph.

In fact, the use of a single recession curve has the disadvantage of varying recession curves in every flood event. Therefore, making a Master Recession Curve (MRC) which is a combination of several single recession curves can be done. In general, MRC can be made using the strip matching method [12] or the correlation method [13]. [14] conducted a study which showed that the strip matching method was more accurate than the correlation method. [15] have created MRC automatically with digital computing which shows that the results of calculations with computational methods have a confidence level of $74 \%$. Meanwhile, research by [16] shows that the single recession curve and MRC are equally good when used to identify flow characteristics on only one recession curve.

Furthermore, one of the uses of MRC is to be able to determine the degree of karstification of an aquifer, as it was first introduced by [17]. Furthermore, [18] has modified the classification to be used in the analysis of karst groundwater sensitivity to pollutants. [19] also used the MRC to calculate the karstic karstification degree to analyze water catchments from two adjacent springs. In Indonesia, the application of calculating the degree of karstification has been carried out by [20] and [21] in the Gunungsewu karst, and [22] in the South Rengel Karst. Meanwhile, [23] and [24] have used MRC combined with time-series analysis to characterize more detailed karst aquifers.

This research was conducted at the Kalisirah, Jumbleng, and Kalikarak springs that located on the north side of the Karangbolong (Gombong) karst area, Kebumen Regency (Figure 1). The three springs flow throughout the year or better known as the perennial spring. The three springs are also used to meet the domestic needs of the community and irrigation for agricultural land (Figure 2). Given the significant benefits of the three springs, it is essential to conduct research related to the characterization of karst hydrological conditions. Specifically, this study aims to analyze the nature of the components of the flood hydrograph, making a Master Recession Curve (MRC) which is then used to estimate the degree of karstification in karst aquifers that recharge Kalisirah, Jumbleng, and Kalikarak Springs. 


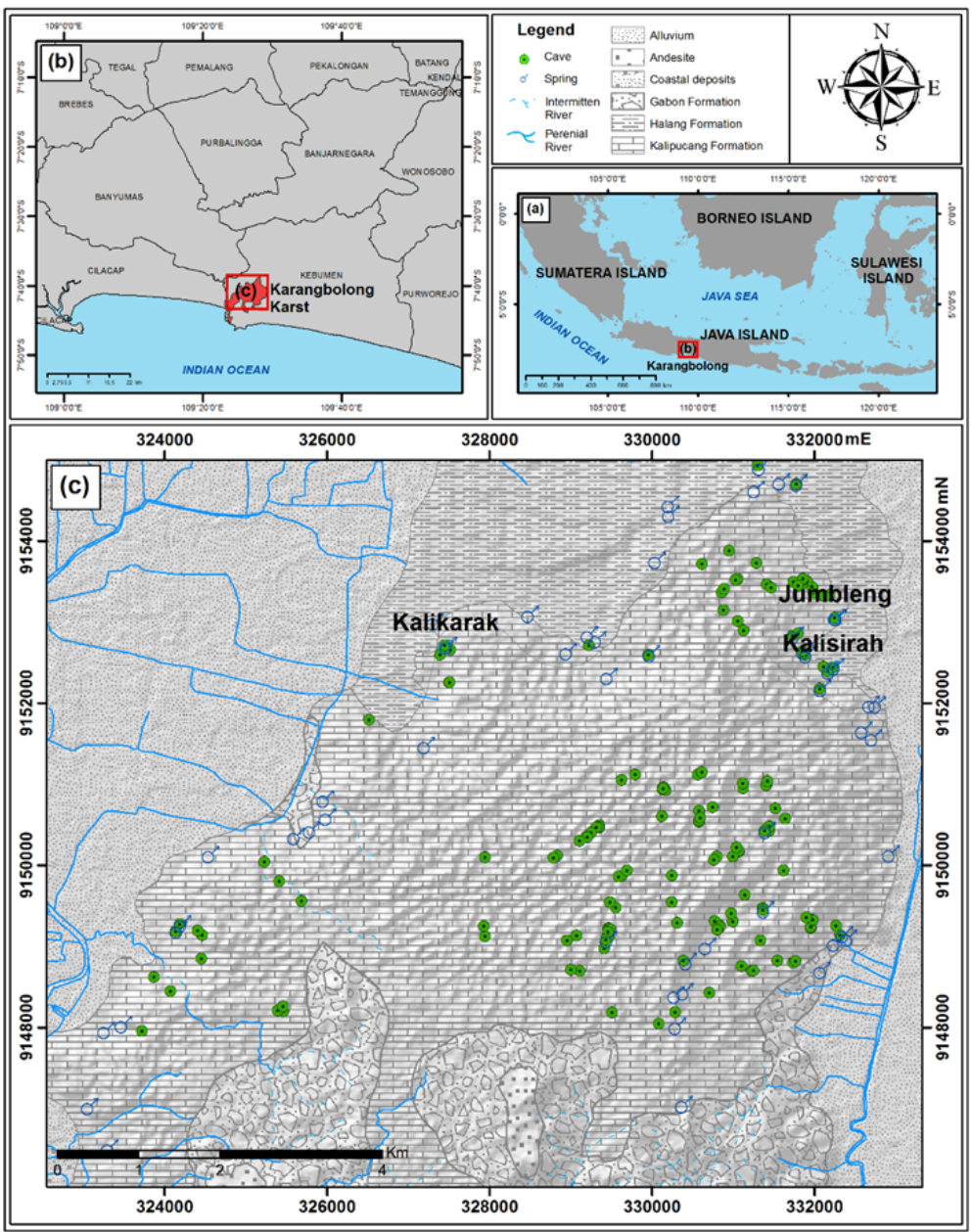

Fig. 1. Research location

\section{Research Method}

Data collection and measurement in the three springs is carried out in different periods, but with a time interval of the recording of the water level (15 minutes). The recording is conducted using the Automatic Water Level Logger Hobo U-30 tool. Data on the water level of Kalisirah spring are recorded from November 25, 2018, to March 7, 2020, Jumbleng springs from February 16, 2019, to March 7, 2020, and Kalikarak springs from May 4, 2019, from March 4, 2020. Measurement of discharge at Kalisirah, Jumbleng, and Kalikarak springs to make rating curves and flow hydrographs are carried out sequentially 22,16 , and 12 times. The chosen discharge calculation method is the velocity area method using current meter and float as a measure of flow velocity. Discharge measurements performed have been representative of when the discharge conditions are low, medium, high, and when a flood occurs. Next, the analysis of the components of the flood hydrograph and the calculation of the MRC to determine the degree of karstification were carried out on the flow hydrograph presented during the measurement period. 

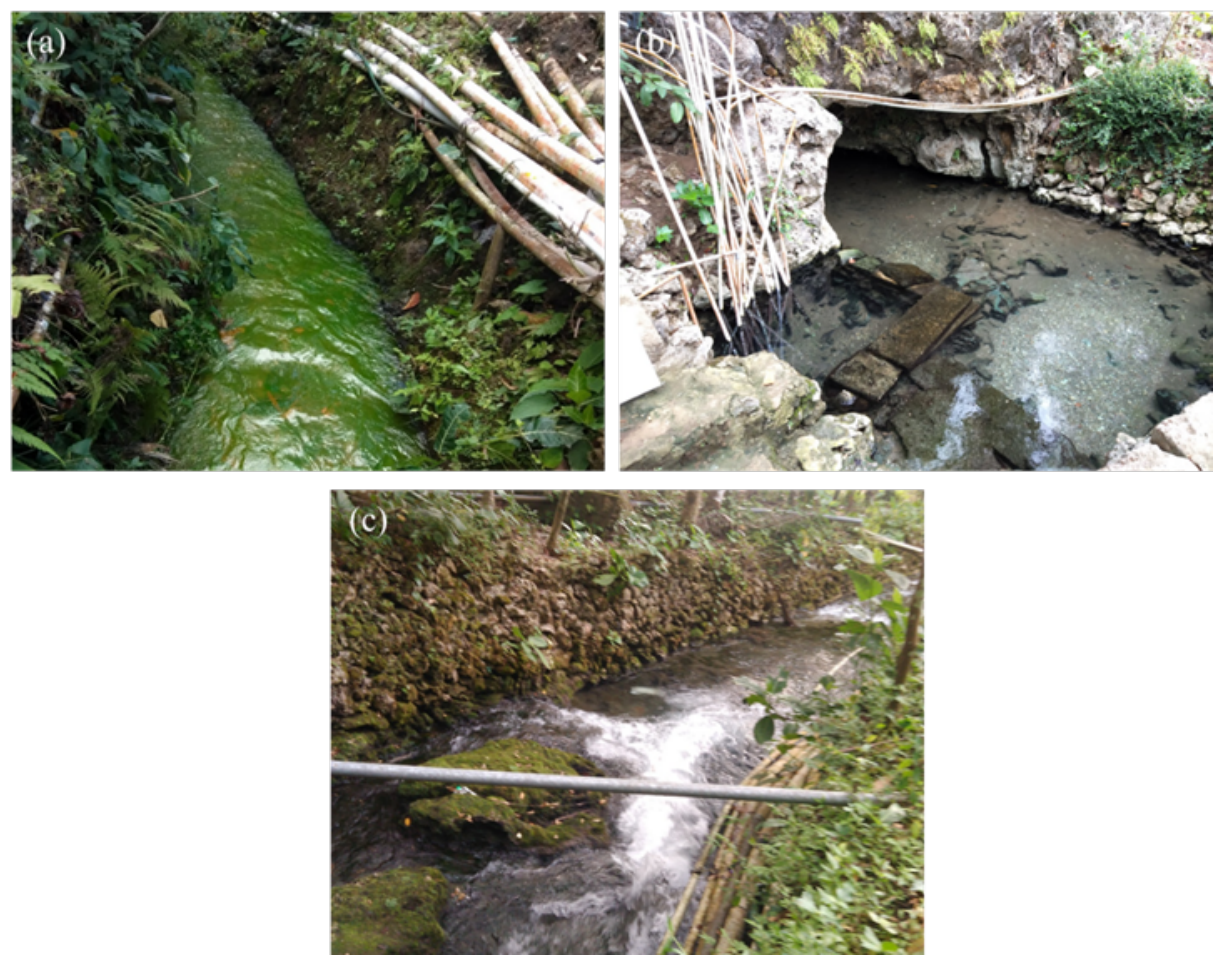

Fig. 2. (a) Kalisirah spring; (b) Jumbleng spring; dan (c) Kalikarak spring which is made a channel to meet domestic and irrigation needs

\subsection{Master Recession Curve (MRC) and Karst Aquifer Degree of Karstification}

The development of digital computing has made the current MRC calculations carried out automatically. [25] used Visual Basic software to calculate MRC using the automatic strip matching method. This study calculates MRC by the strip matching method with the help of RC 4.0 software. This software is relatively user friendly and is able to calculate MRC automatically or semi-automatically [26].

In this study, the MRC was made using two recession equations, namely simple exponential (1) for the type of laminar flow (diffuse flow) and linear turbulent (2) for the type of turbulent flow (conduit flow). According to [19], flood events can consist of several laminar and turbulent flows, as presented in Figure 3. Furthermore, the presence of laminar or turbulent flow types under recession conditions is used to determine the degree of karstification. The karstification degree consists of ten classes which show that the most developed karst has the highest degree [18].

$$
\begin{aligned}
& Q_{t}=Q_{0} e^{-\alpha t} \\
& Q_{t}=Q_{0}(1-\beta t)
\end{aligned}
$$




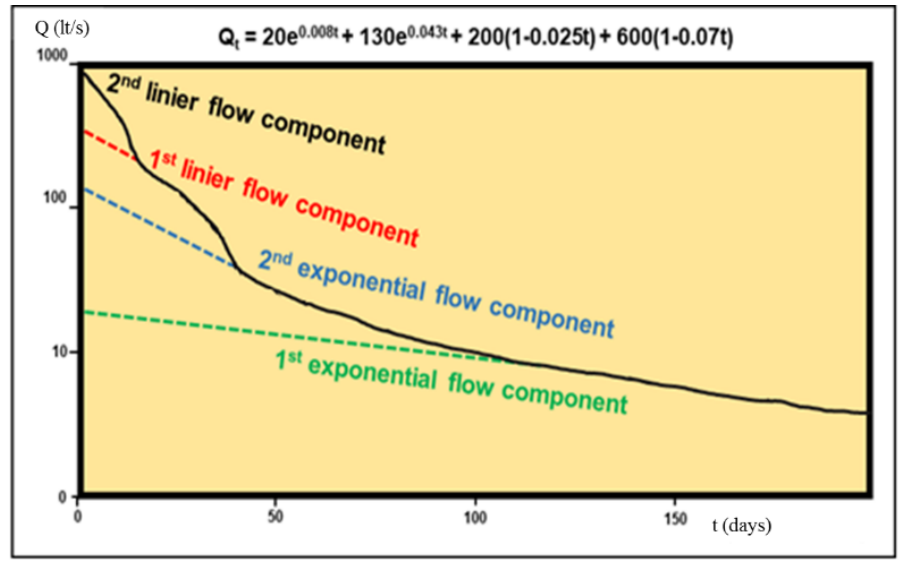

Fig. 3. Illustration of MRC with 2 types of exponential and linear flow (adopted from [19])

\subsection{Flood Hydrograph Characteristics}

The flood hydrograph is shaped like a bell that is tilted to the right and consists of several components, namely time lag $\left(T_{m s}\right)$, peak discharge $\left(Q_{p}\right)$, and time to base flow $\left(T_{b}\right) . T_{b q}$ is the time interval between the peak of the rainfall event to the peak discharge, $Q_{p}$ is the peak discharge of the flood event, and $T b$ is the time interval between $Q_{p}$ until the base flow is reached again. Flood hydrographs can be used as indicators in the characterization of karst aquifers because of their shape or components that reflect the condition of the catchment area, the size of the storage, and how the nature of the aquifer to release its storage [27]. [28] used flood hydrographs to characterize aquifers in the Pindul Cave Karst System. This study calculates $\mathrm{T}_{\mathrm{bs}}, \mathrm{Q}_{\mathrm{p}}$, and $\mathrm{T}_{\mathrm{b}}$ in each flood events that occur in Kalisirah, Jumbleng, and Kalikarak springs.

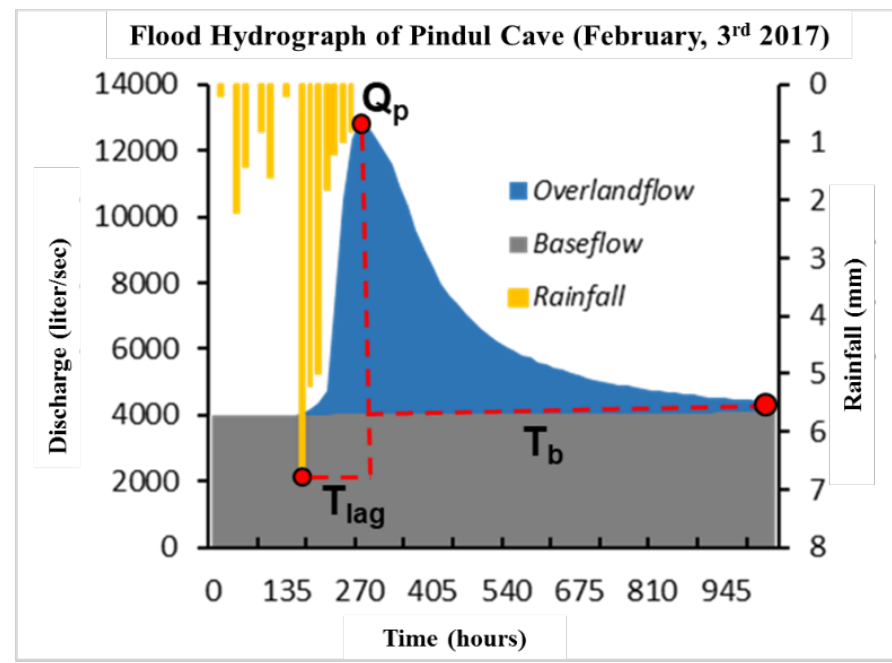

Fig. 4. Illustration of flood hydrograph consisting of time lag $\left(\mathrm{T}_{\mathrm{lag}}\right)$, peak discharge $\left(\mathrm{Q}_{\mathrm{p}}\right)$, and time to base flow $\left(T_{b}\right)$ (adopted from [28]) 


\section{Results and Discussion}

\subsection{Discharge and Flood Hydrograph Characteristics}

The relationship between discharge (y) and water level (x) results from recording at the three springs during the measurement period results in a stage-discharge rating curve, as presented in Table 1. The stage-discharge rating curve is then used to calculate the discharge hydrographs continuously during the period of study in each spring. The rating curve in Table 1 shows a good correlation between flow rates (y) and water level (x) for each spring with a determination value $\left(\mathrm{R}^{2}\right)$ between $0.91-0.95$.

Table 1. Stage discharge rating curve of Kalisirah, Jumbleng, dan Kalikarak springs

\begin{tabular}{|l|c|c|c|}
\hline Springs & $\begin{array}{c}\text { Number of discharge } \\
\text { measurements }\end{array}$ & Stage-discharge rating curve & $\mathrm{R}^{2}$ \\
\hline Kalisirah & 22 & $y=2307 x^{2,134}$ & 0,95 \\
\hline Jumbleng & 16 & $y=3179,4 x^{3,3181}$ & 0,94 \\
\hline Kalikarak & 12 & $y=1758,1 x^{1,9166}$ & 0,91 \\
\hline
\end{tabular}

Next, the discharge-hydrograph during the study period in the three springs is presented in Figure 5. Figure 5a is the hydrograph discharge of the Kalisirah spring. The time of data collection at Kalisirah spring includes two rainy seasons and one dry season. The first rainy season period starts from November 2018 to May 2019. This period has 14 flood events, and there is the highest flooding during the research period, which is on January 16, 2019, with a peak discharge of 3,374.63 litres/second. The second rainy season period that entered into the study period is starting from January to March 2020. Flood events in that period were as many as six flood events. The dry season period starts from May 2019 to December 2019. The lowest discharge during the study period occurred in the middle of December 2019.

Figure $5 \mathrm{~b}$ shows the discharge-hydrograph in Jumbleng spring consisting of two periods of the rainy season and one period of the dry season. The first rainy season period starts from February 2019 to May 2019. The period experienced seven flood events with the highest flood occurring on March 16,2019, with a peak discharge of 149.52 litres/second. The second rainy season period starts from January to March 2020, which has eight flood events. The biggest flood in this period occurred on March 5, 2020, and was the largest flood during the study period with a peak discharge of 183.02 litres/second. The dry season period in this study occurred from May 2019 to December 2019, with the lowest discharge occurring at the end of December 2019.

Figure 5c shows the discharge-hydrograph at Kalikarak spring which consists of one dry season period and one rainy period. The dry season period starts from May 2019 to November 2019, and the lowest discharge occurs at the end of October 2019. The rainy season period starts from November 2019 to March 2020. During this period, there were ten flood events. The biggest flood event occurred on March 2, 2020, with a peak discharge of 826,058 litres/second. 
(a)

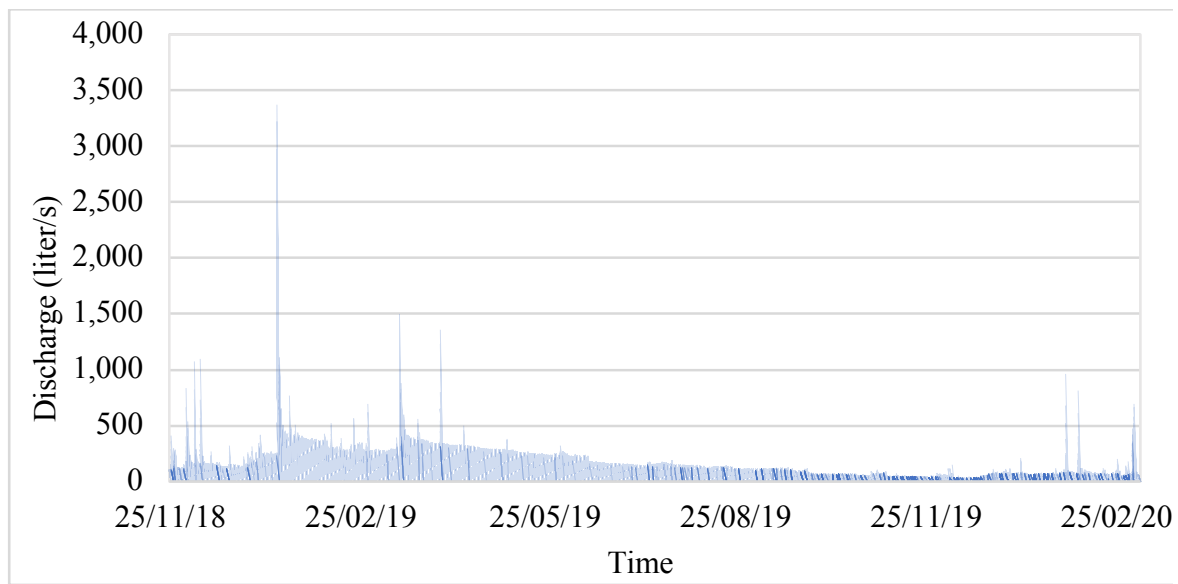

(b)

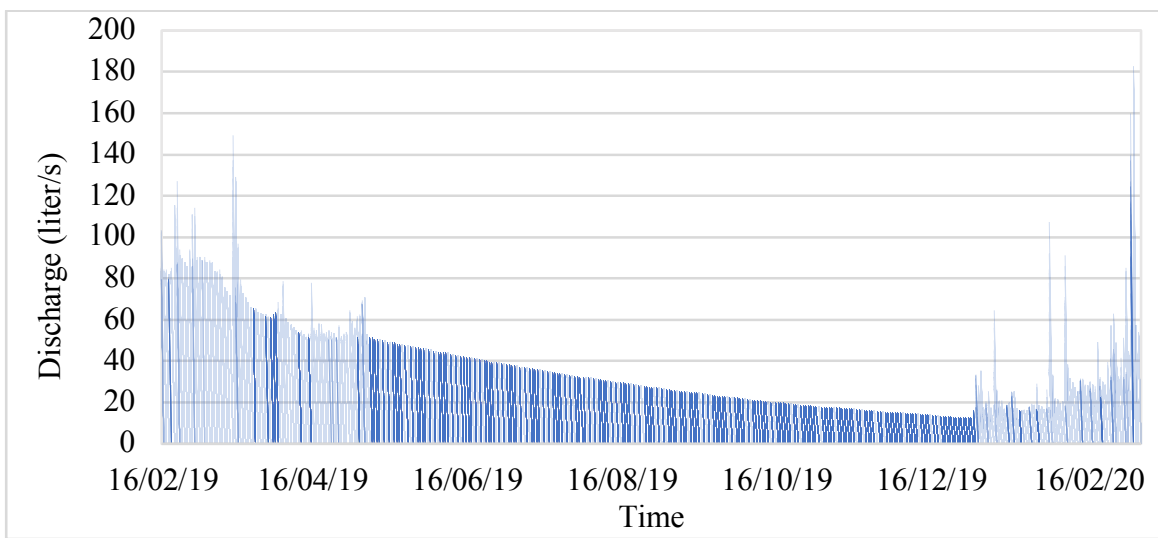

(c)

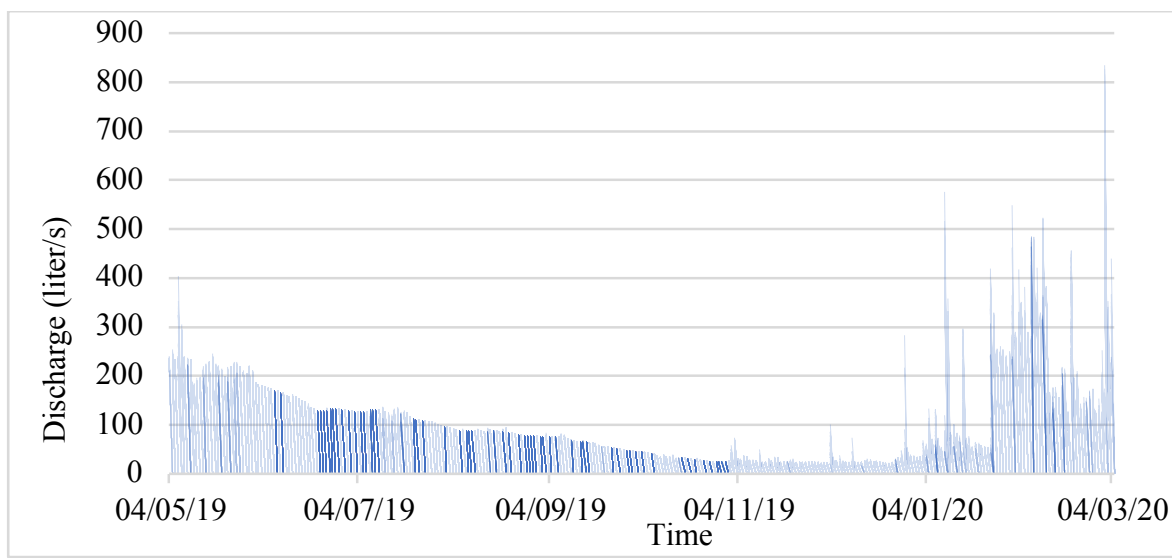

Fig. 5. Discharge hydrograph of (a) Kalisirah; (b) Jumbleng; and (c) Kalikarak

Furthermore, the analysis of flood hydrograph components is carried out on eight to nine flood events, because not all flood events can be calculated for hydrographic components. Analysis of the components of flood hydrographs can only be conducted on flood hydrographs that have a single peak and a visible recession period [29]. In this analysis, Kalisirah and Kalikarak springs use eight flood events, while Jumbleng springs use nine flood events. Table 2 presents the mean results of $T_{b s}, Q_{p}$, and $T_{b}$ calculations in the three springs. 
Table 2 shows that the average peak discharge (Qp) at Kalisirah springs has the highest value compared to the other two springs, which is 942.23 litres/second. Delay time $\left(T_{\text {man }}\right)$ Kalisirah spring is classified as fast at 1.94 hours, the second largest after Kalikarak spring. This reflects the development of a conduit-sized void type in the karst system that recharges Kalisirah springs. The time to base flow $\left(\mathrm{T}_{\mathrm{b}}\right)$ of Kalisirah spring is 20.84 hours, the secondhighest after Kalikarak spring.

Kalikarak spring has the second highest peak discharge, which is 297.73 litres/second. Time lag (Tlag) Kalikarak spring is the fastest, which is 1.44 hours. However, the time to reach the base flow ( $\mathrm{Tb}$ ) of Kalikarak spring is also the longest, which is 31.34 hours. These conditions reflect that the development of conduit type cracks in aquifers that affix Kalikarak Springs is already quite high, but the aquifer is also still useful in storing groundwater in small voids (diffuse).

Jumbleng spring has the lowest peak discharge rate, which is 113.99 litres/second. The delay time (Tlag) at Jumbleng spring is the longest compared to the other two springs, which is 2.69 hours. This shows that the development of conduit-sized void types in aquifer systems that affect Jumbleng Springs is also the lowest. Meanwhile, the time to base flow (Tb) at Jumbleng spring is the fastest, at 17.25 hours. This reflects that karst aquifers that recharge Jumbleng springs have the fastest time in releasing groundwater storage in diffuse-sized voids.

Table 2. Comparison of flood components characteristic in Kalisirah, Jumbleng and Kalikarak springs

\begin{tabular}{|l|r|r|r|}
\hline $\begin{array}{c}\text { Flood hydrograph } \\
\text { parameters }\end{array}$ & \multicolumn{1}{|c|}{ Kalisirah } & Jumbleng & Kalikarak \\
\hline $\mathrm{T}_{\mathrm{bs}}$ (hour) & 1.94 & 2.69 & 1.44 \\
\hline $\mathrm{Q}_{\mathrm{p}}$ (litre/sec) & 942.23 & 113.99 & 297.73 \\
\hline $\mathrm{T}_{\mathrm{b}}$ (hour) & 20.84 & 17.25 & 31.34 \\
\hline
\end{tabular}

\subsection{MRC of Kalisirah, Jumbleng, dan Kalikarak springs}

The single recession curves (RC) that make up the Kalisirah, Jumbleng, and Kalikarak spring MRCs are six, five, and ten RC, respectively. Figure 6 shows the MRC in all three springs. Kalisirah and Kalikarak springs have one type of linear reservoir recession and two types of turbulent flow recession. The Jumbleng spring has one type of linear reservoir recession and one type of turbulent flow recession. The linear recession type indicates the start of diffuse flow release, while the turbulent flow recession type characterizes the type of conduit flow released by karst aquifers that recharge springs. The second type of turbulent recession shows that there is a more develop conduit void that is able to release water flow faster. 
(a)

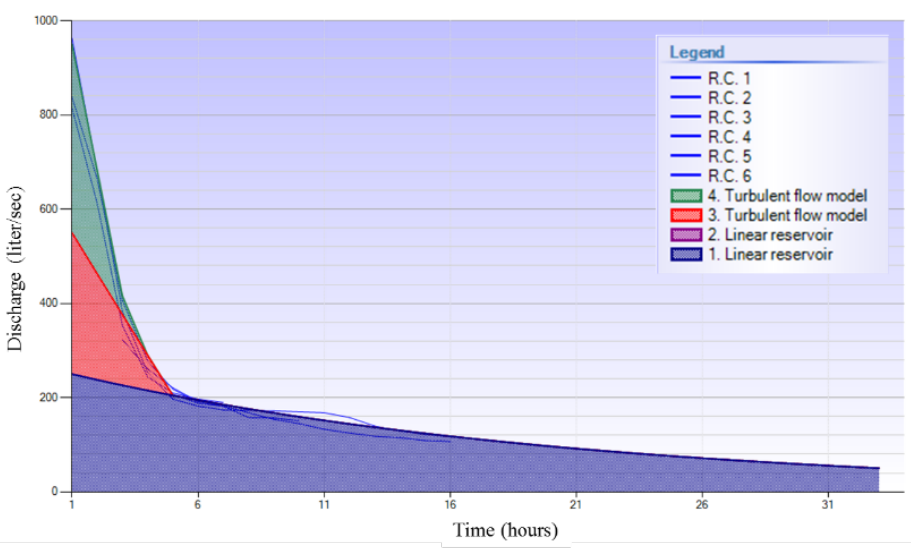

(b)

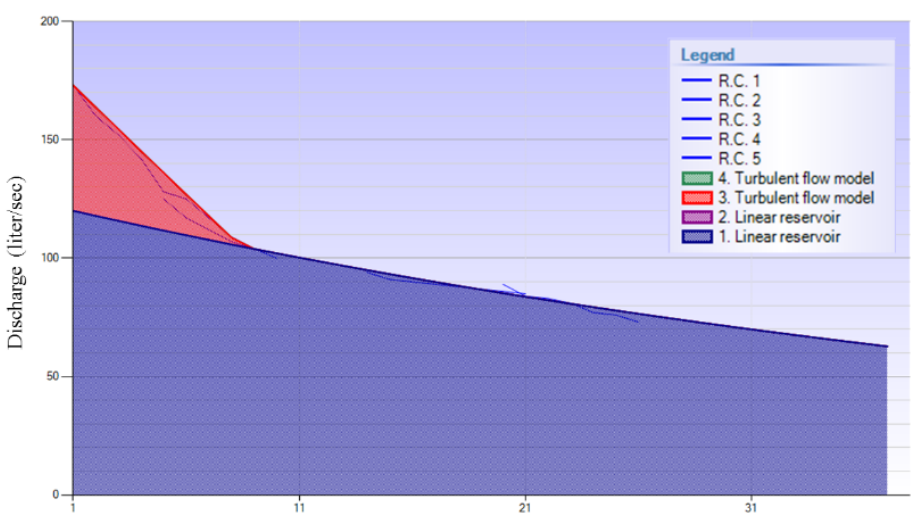

Time (hours)

(c)

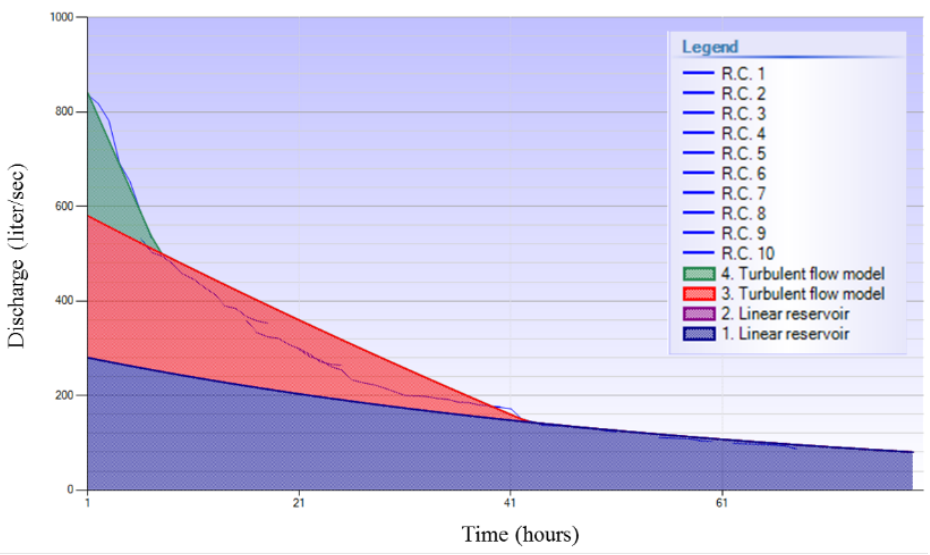

Fig. 6. Master Recession Curve (MRC) of (a) Kalisirah; (b) Jumbleng; (c) Kalikarak springs

MRC formed from several RCs is a reflection of the karst aquifer characteristics in releasing its flow storage. Based on this concept, Kalisirah spring has a conduit flow release time of 0 to 5 hours, Jumbleng spring 0-9 hours, and Kalikarak spring 0-42 hours. The release time of base flow (Tb-diffuse) at Kalisirah spring is more than 5 hours, Jumbleng spring is more than 9 hours, and Kalikarak spring is more than 40 hours. 


\subsection{Degree of Karstification (Dk) of Karst Aquifer in Kalisirah, Jumbleng, dan Kalikarak springs}

The results of the MRC analysis of the three springs show the complexity of the flow regime, as presented in Table 3. The equation of the Kalisirah and Kalikarak spring MRCs consists of one type of linear/laminar reservoir recession and two types of turbulent flow recession, whereas in Jumbleng spring consists of one linear recession / laminar reservoir and one turbulent flow recession. Based on the classification by [18], Kalisirah and Kalikarak springs have a karstification degree of 8 with a karst aquifer that has been increasingly developed with predominantly conduit-sized voids (small fracture densities and micro-fissures are decreasing). Here, the role of the phreatic level is already insignificant in releasing groundwater storage. On the other hand, Jumbleng springs have a karstification degree of 5 by still dominating the laminar flow from diffuse-type voids, while conduit sized voids have not developed much. Here, aquifers have a small network that is open and combined with some systems that have developed towards conduit in the phreatic zone.

Tabel 3. Flow regimes complexity in the Kalisirah, Jumbleng, and Kalikarak Springs

\begin{tabular}{|c|c|c|c|c|c|c|c|c|c|c|}
\hline $\begin{array}{l}\text { Mata } \\
\text { air }\end{array}$ & $\begin{array}{c}\text { Sub- } \\
\text { regime } \\
1\end{array}$ & $\begin{array}{l}\mathbf{Q}_{0} \\
*\end{array}$ & $\mathbf{k} * *$ & $\begin{array}{c}\text { Sub- } \\
\text { regime } \\
2\end{array}$ & $\mathbf{Q}_{\text {。 }}$ & $\mathbf{k}$ & $\begin{array}{c}\text { Sub- } \\
\text { regime } \\
3\end{array}$ & $\begin{array}{l}\mathbf{Q}_{*} \\
*\end{array}$ & $\mathbf{k}^{* *}$ & $\begin{array}{l}\text { D } \\
\text { k }\end{array}$ \\
\hline $\begin{array}{l}\text { Kalisira } \\
\mathrm{h}\end{array}$ & $\begin{array}{l}\text { Lamina } \\
\mathrm{r} \\
\text { reservoi } \\
\mathrm{r}\end{array}$ & $\begin{array}{r}25 \\
0\end{array}$ & $\begin{array}{r}0.05 \\
0\end{array}$ & $\begin{array}{l}\text { Turbule } \\
\text { nt flow } \\
\text { model }\end{array}$ & $\begin{array}{r}30 \\
0\end{array}$ & $\begin{array}{r}0.25 \\
0\end{array}$ & $\begin{array}{l}\text { Turbule } \\
\text { nt flow } \\
\text { model }\end{array}$ & $\begin{array}{r}40 \\
0\end{array}$ & $\begin{array}{r}0.4 \\
5\end{array}$ & 8 \\
\hline $\begin{array}{l}\text { Jumblen } \\
\mathrm{g}\end{array}$ & $\begin{array}{l}\text { Lamina } \\
\mathrm{r} \\
\text { reservoi } \\
\mathrm{r}\end{array}$ & $\begin{array}{r}12 \\
0\end{array}$ & $\begin{array}{r}0.01 \\
8\end{array}$ & $\begin{array}{l}\text { Turbule } \\
\text { nt flow } \\
\text { model }\end{array}$ & 53 & $\begin{array}{r}0.13 \\
5\end{array}$ & & & & 5 \\
\hline $\begin{array}{l}\text { Kalikara } \\
\mathrm{k}\end{array}$ & $\begin{array}{l}\text { Lamina } \\
\mathrm{r} \\
\text { reservoi } \\
\mathrm{r}\end{array}$ & $\begin{array}{r}28 \\
0\end{array}$ & $\begin{array}{r}0.01 \\
6\end{array}$ & $\begin{array}{l}\text { Turbule } \\
\text { nt flow } \\
\text { model }\end{array}$ & $\begin{array}{r}30 \\
0\end{array}$ & $\begin{array}{r}0.02 \\
4\end{array}$ & $\begin{array}{l}\text { Turbule } \\
\text { nt flow } \\
\text { model }\end{array}$ & $\begin{array}{r}26 \\
0\end{array}$ & $\begin{array}{r}0.1 \\
5\end{array}$ & 8 \\
\hline
\end{tabular}

*Initial discharge; **recession constant

The development of conduit-sized void types in recharging the aquifers Kalisirah springs is evidenced by the existence of a sinkhole in the Pucung and Jeblosan Caves where the water enters the karst aquifer, which then appears in the Kalisirah spring [30]. The peak flood time (Tp) at Kalisirah spring, which is classified as fast (average 1.94 hours) also reflects the existence of conduit flow (quick-flow) during a rainy event (Table 2). 


\section{Conclusion}

Calculation of karstification degree shows that Kalisirah and Kalikarak springs have the same degree of karstification (Dk) in grade 8, while Jumbleng springs in grade 5. Dk values indicate that Kalisirah and Kalikarak springs have more developed conduit-sized voids than those encountered in Jumbleng spring. The results of the analysis of the flood hydrograph component corroborate the calculation results of Dk at each spring. The time to peak (Tlag) of the Kalisirah and Kalikarak springs (1.94 and 1.44 hours) is relatively faster than the Jumbleng Spring (2.69 hours) which shows a more developed flow of conduit during rain events. In addition, the calculation of time to base flow (Tb) by manual using flood hydrograph in Kalisirah spring is 20.84 hours, Jumbleng spring (17.25 hours), and Kalikarak spring (31.34) hours. These results indicate that karst aquifers that recharge Kalikarak springs have the longest water retention time, whereas karst aquifers that recharge Jumbleng springs have the shortest time to store groundwater.

\section{Acknowledgements}

The finalization of this research was made possible by funding from Hibah Penelitian Mandiri Dosen, Faculty of Geography, Universitas Gadjah Mada (1933/UN1/FGE/SETD/M/2020, date April 28 2020). The author would like to thank Karst Research Group, Faculty of Geography, Universitas Gadjah Mada for assisting in the field data collection process. The author also thanks the Karst Gombong Rescue People's Union (PERPAG) who has cooperated in carrying out field activities and providing supervisory facilities so that this research can take place without significant obstacles. 


\section{References}

1. D. Ford and P. Williams, Karst Geomorphology and Hydrology (London, Chapman and Hall, 1989)

2. P. Y. Jeannin and M. Sauter, Analysis of karst hydrodynamic behaviour using global approaches: a review Bulletin d'Hydrogéologie, Neuchatel 16, 31-48 (1998)

3. O. Bonacci, Karst Springs Hydrographs as Indicators of Karst Aquifers, Hydrol. Sci. J. 38, 51-62 (1993)

4. B. S. Barnes, The structure of discharge-recession curves, Eos Trans. AGU 20, 721725 (1939)

5. E. Haryono, Danardono, S. Mulatsih, S. T. Putro, and T. N. Adji, The Nature of Carbon Flux in Gunungsewu Karst, Java-Indonesia, Acta Carsologica 45, 173-185 (2016)

6. T. N. Adji and I. Y. Bahtiar, Rainfall-discharge relationship and karst flow components analysis for karst aquifer characterization in Petoyan Spring, Java, Indonesia, Environ. Earth Sci. 75, (2016)

7. T. N. Adji, E. Haryono, H. Fatchurohman, and R. Oktama, Spatial and temporal hydrochemistry variations of karst water in Gunung Sewu, Java Indonesia, Environ. Earth Sci. 76, (2017)

8. T. N. Adji, E. Haryono, A. Mujib, H. Fatchurohman, and I. Y. Bahtiar, Assessment of aquifer karstification degree in some karst sites on Java Island, Indonesia, Carbonates and Evaporites 32, 1-14 (2017)

9. A. Nurkholis, T. N. Adji, E. Haryono, A. Cahyadi, and R. F. Agniy, Spatial and temporal variation of flow characteristics to aquifer characterizations of Pindul Karst System, Gunungkidul Regency, in Proceeding of 2nd annual conference of groundwater expert association (PIT-PAAI) (2017)

10. E. Maillet, Essais d'Hydr aulique Souterraine et Fluvi ale, Hermann Paris 218 (1905)

11. L. M. Tallaksen, A review of baseflow analysis, J. Hydrol. 165, 349-370 (1995)

12. F. F. Synder, A concept of runoff-phenomena, Eos Trans. AGU 20, 25-738 (1939)

13. W. B. Langbein, Some channel storage studies and their application to the determination of infiltration, Eos Trans. AGU 19, 435-447 (1938)

14. R. J. Nathan and T. A. McMahon, Evaluation of automated techniques for baseflow and recession analyses, Water Resour. Res 7, 1465-1473 (1990)

15. J. G. Arnold, P. M. Allen, R. Muttiah, and G. Bernhardt, Automated base flow separation and recession analysis techniques, Groundwater 33, 1010-1018, 1995.

16. S. Berhail, L. Ouerdachi, and H. Boutaghane, The use of the recession index as indicator for components of flow, Energy Procedia 18, 741-750 (2012)

17. E. Kullman, "Nove metodicke pristupy $k$ rieseniu ochrany a ochrannych pasiem zdrojov podzemnych vod $v$ horni- novych prostrediach a krasovopuklinovou a puklinovou priepustnostou, Podzem. voda 6, 31-41 (2000)

18. P. Malik, Assessment of regional karstification degree and groundwater sensitivity to pollution using hydrograph analysis in the Velka Fatra Mountains, Slovakia, Environ. Geol. 51, 707-711 (2007)

19. P. Malík and S. Vojtková, Use of recession-curve analysis for estimation of karstification degree and its application in assessing overflow/underflow conditions in closely spaced karstic springs, Environ. Earth Sci. 65, 2245-2257 (2012)

20. H. Fatchurohman, Characterization and management of karst drainage system based on 
hydrograph analysis in Gunung Sewu Karst Area, Master thesis, (Universitas Gadjah Mada, 2017)

21. H. Fatchurohman, T. N. Adji, E. Haryono, and P. Wijayanti, Baseflow index assessment and master recession curve analysis for karst water management in Kakap Spring, Gunung Sewu, in IOP Conf. Series: Earth and Environmental Science 148 (2018)

22. M. . A. Mujib, Analisis karakteristik dan tingkat karstifikasi akuifer karst di sistem Mata air Ngerong, Kecamatan Rengel, Kabupaten Tuban, Master thesis, (Unversitas Gadjah Mada, 2015)

23. A. Nurkholis, T. N. Adji, E. Haryono, A. Cahyadi, and S. Suprayogi, Time series analysis application for karst aquifer characterization in pindul cave Karst system, Indonesia, Acta Carsologica 48, 69-84, (2019)

24. I.A. Kurniawan, T.N. Adji, A. Nurkholis, E. Haryono, H. Fatoni, W.A. Waskito, A. Cahyadi, R.F. Agniy, Karst aquifer response by time series analysis applications in Jonggrangan Karst, Java Island, Indonesia, Environmental Earth Sciences, 78:379, doi: 10.1007/s12665-019-8386-x (2019)

25. K. Posavec, A. Bacani, and Z. Nakic, "A visual basic spreadsheet macro for recession curve analysis," Groundwater 44, 764-767 (2006)

26. M. Gregor and P. Malik, RC 4.0 User's Manual Hydro Office Sofware for Water Science (2010)

27. T. N. Adji, E. Haryono, H. Fatchurohman, and R. Oktama, Diffuse flow characteristics and their relation to hydrochemistry conditions in the Petoyan Spring, Gunungsewu Karst, Java, Indonesia, Geosci. J. 20, 381-390 (2016)

28. A. Nurkholis, A. Cahyadi, and R. F. Agniy, Spatial and temporal flood characterization of Pindul Karst System, Gunungkidul Regency, in IOP Conf. Series: Earth and Environmental Science 145 (2018)

29. E. F. Schulz, Problems in Applied Hydrology (Colorado, Water Resource Publication, 1976)

30. E. S. Astuti, A.I. Rahmawati, A. Setyawan, Q. Alghozali, R.F. Agniy, D.R. Fauzi, D.S. Mahrizkhal, A. Nurkholis, A.D. Pratama, D.S. Dwiputra, G.E. Laksono, A.D. Siswanto, T.N. Adji, E. Haryono, A Groundwater Tracing Investigation to Determine Kalisirah Karst Springs Catchment Area, Kebumen Regency, Central Java, in The 3rd Environmental Resource Management in Global Region. IOP Conference Series: Earth and Environmental Science 451 (2020) 